\title{
Monitoring Backup GSM Network to Handle Disorders on M2M SIM Cards Using Zabbix and SecureCRT
}

\author{
Mega Evia Maharani \\ Informatics and computer engineering \\ Jakarta State Polytechnic \\ mega.maharani.tik15@mhsw.pnj.ac.id
}

\begin{abstract}
Electricity is one of the main needs of society, where now various equipment uses electricity as its energy source. In 2017, Indonesia's electricity consumption reached 1,012 Kilowatt per Hour $(\mathrm{KWH}) /$ capita, up 5.9 percent from the previous year. Therefore, the electricity supply to each region must be fulfilled and control the status of the distribution substation that provides electricity supply for each region. Control can be facilitated by utilizing ICT, which is using network monitoring regarding the status of distribution substations. Network monitoring is carried out on GSM back up networks with the form of M2M SIM cards that have been installed on routers in each distribution substation that connected to the SCADA network. The GSM network is monitored using Zabbix which is one of the monitoring software to determine the interference that occurs in the M2M SIM card and ensuring data transmission using a GSM backup network can run in replacing data transmission on the main network. M2M SIM card interference that exceeds the time limit, it will be handled using SecureCRT software by telnet to the router that is on the distribution substation.
\end{abstract}

Keywords-SCADA, M2M SIM Card, Network Management System, Zabbix.

\section{INTRODUCTION}

Do you know about Network Monitoring System? Network Monitoring System is a system that helps operators and network administrators in charge of supervising and managing the computer network in an institution. One of the software that is commonly used for network monitoring is Zabbix, this software is an open source network monitoring system that can use for real-time monitoring. Zabbix already has a GUI that makes it easy for users to use, the GUI display is in the form of maps and graphs so that it helps with administrative and system settings. this network monitoring system is used to monitor distribution substations that send electricity to various homes to support daily life in every region of Indonesia. Therefore, it is necessary to monitor the status of the distribution substations so that the electricity supply for the area around the distribution substation is fulfilled. Network monitoring regarding sending data to distribution substations using Zabbix software to determine the interference on M2M SIM card. Interference with M2M SIM cards can interfere with the process of sending data to distribution substation. When the M2M SIM card has an error in sending data, then the $\mathrm{m} 2 \mathrm{~m}$ SIM card will be resolved by itself. If the disruption of the M2M SIM card is not completed within 15 minutes to 3 hours, it must be handled using SecureCRT software by telneting to the lastmile router on the distribution substation. The use of Zabbix software is for network monitoring, while SecureCRT is used to handle interference with M2M SIM cards.

PT XYZ is a professional consulting and contracting company specializing in telecommunications and network information systems. PT Datakom Strata Tiga is one of the ICON + vendors that handles the installation, monitoring, and handling of disruptions of M2M SIM cards in the distribution substations.

The device used is an Icon Plus box that is connected and integrated with devices that are in the distribution substation using the SCADA network. Data transmission is done using a Cisco 819 router or referred to as a lastmile router in the Icon Plus box using optical fiber transmission media as the main media and GSM network in the form of M2M SIM cards as backups. Network monitoring is done separately because of the difference between the transmission media used. The GSM network is monitored using Zabbix which is one of the monitoring software to determine the interference that occurs in M2M SIM cards. Interference with M2M SIM cards can occur due to improper antenna 
positioning so that it gets a bad signal or even due to bad weather.

\section{LITERATURE REVIEW}

\section{A. SCADA}

SCADA (Supervisory Control and Data Aqcuisiton) is a distribution system to control an asset or plant in various places where centralized control and data acquisition of the plant is very necessary. The SCADA control center is a place where plant data is processed and monitored so that there is data management in which monitoring, alarming and controlling functions are also used [1]. SCADA is used as a control system and data retrieval under supervision (operator). SCADA is used for monitoring and controlling networks on lastmile routers that have M2M SIM cards installed.

\section{B. M2M SIM Card}

M2M (Machine to Machine) SIM Card is an M2M service portal that offers the opportunity to manage and control everything centrally. This M2M SIM card can monitor the cards used as well as the devices and data involved regarding companies that have used the M2M service portal [2]. M2M SIM cards used are M2M SIM cards developed by Telkomsel, supported by Telkomsel M2M Control Center and Telkomsel M2M Application Platform. This Telkomsel M2M Control Center makes it easy for companies to run, manage, and monitor connected devices owned. Whereas Telkomsel M2M Application Platform allows companies to integrate, implement, and manage devices and information from cloud-based devices, so businesses can monitor what is happening in the field without having to come to that place [3].

\section{Network Management System (NMS)}

Network Management System (NMS) is a system used to regulate and monitor network devices based on Internet Protocol (IP). NMS allows network administrators to manage network services remotely. This is very important because with the presence of NMS, the administrator's work will be lighter in monitoring and managing the state of the system and network devices [4].

\section{Network to Network Interface (NNI)}

The Network to Network Interface (NNI) feature of the Cisco Unified Border Element provides the ability to create and maintain secure connections between two different network service providers or between service provider networks and company businesses. The relationship between two different networks is the SIP bar [5].

\section{E. Zabbix}

Zabbix is an open source based software that serves to conduct network monitoring. Zabbix can directly check network conditions and some services that are in a network device. Network inspection is carried out directly on host services including Disk Usage, Memory Usage, CPU Usage, Ping and Traffic bandwidth with the SNMP (Simple Network Management Protocol) protocol. Zabbix also supports system notifications to administrators with the help of SMS Gateway and Email. Zabbix uses MySQL to store data as a database. Backend is written in $\mathrm{C}$ language and web frontend is written using PHP [6].

\section{F. SecureCRT}

SecureCRT is a rock-solid terminal emulation software from VanDyke Software to increase productivity with advanced session management and save time by streamlining repetitive tasks. SecureCRT provides secure remote access, file transfer and data tunneling. SecureCRT functions for GUI-based telnet client and terminal emulators using SSH security [7].

\section{ANALYSIS}

\section{A. Topology}

We need to know the network topology that will be monitored. The following is the topology of the SCADA network with M2M SIM cards. SCADA Network has spread to distribution substations located in Jakarta, Denpasar, Bali, Lampung, Medan and Sumbagsel areas. Therefore, in each of these areas there is also a data center for each region.

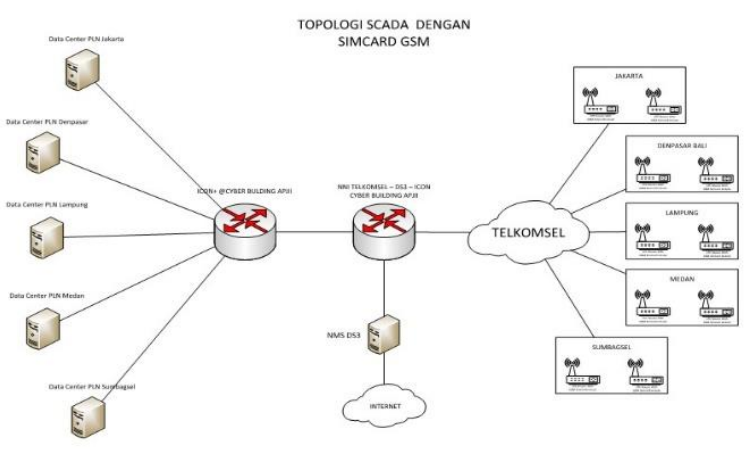

Fig. 1. Network Topology SCADA with SIM card 
Table 1.

device function in topology

\begin{tabular}{|c|c|}
\hline Device & Function \\
\hline $\begin{array}{c}\text { Cloud } \\
\text { Telkomsel }\end{array}$ & $\begin{array}{l}\text { As a service used for sending } \\
\text { data from lastmile routers using } \\
\text { GSM network media to } \\
\text { Network to Network Interface } \\
\text { (NNI). }\end{array}$ \\
\hline Router ICON+ & $\begin{array}{l}\text { As a liaison from all data } \\
\text { centers in various regions with } \\
\text { Network to Network Interface } \\
(\mathrm{NNI}) \text {. }\end{array}$ \\
\hline $\begin{array}{l}\text { NNI (Network } \\
\text { to Network } \\
\text { Interface) - } \\
\text { Router Cisco } \\
\text { seri } 3945\end{array}$ & $\begin{array}{l}\text { As a cyber and data center that } \\
\text { connects the Telkomsel } \\
\text { network with the SCADA } \\
\text { network and as a data } \\
\text { distributor to the Network } \\
\text { Management System (NMS). }\end{array}$ \\
\hline $\begin{array}{c}\text { NMS (Network } \\
\text { Management } \\
\text { System) - } \\
\text { Server seri } \\
\text { Supermikro } \\
183\end{array}$ & $\begin{array}{l}\text { As a tool for monitoring / } \\
\text { monitoring GSM backup } \\
\text { networks on lastmile routers } \\
\text { using Zabbix software. }\end{array}$ \\
\hline $\begin{array}{c}\text { MikroTik seri } \\
951\end{array}$ & $\begin{array}{l}\text { As a liaison for the Network } \\
\text { Management System (NMS) } \\
\text { with the internet because } \\
\text { accessing Zabbix requires } \\
\text { internet. }\end{array}$ \\
\hline
\end{tabular}

The work system on the topology starts from the Network to Network Interface (NNI) in the form of a Cisco 3945 series router device. The Cisco 3945 series router functions as a cyber and data center that connects between Telkomsel networks and SCADA networks. SCADA or Supervisory Control and Data Acquisition network is a control and data retrieval system under supervision (operator), in this topology SCADA is used for network monitoring. Meanwhile, Telkomsel's network has been connected to lastmile routers located in the distribution substations in the areas of Jakarta, Denpasar, Bali, Lampung, Medan and Sumbagsel.

Cisco routers 3945 series as Network to Network Interface (NNI) will get data about lastmile routers, which will be channeled to the Network Management System (NMS) to be monitored through Zabbix software. Network Management System (NMS) is a tool for monitoring or monitoring elements contained in computer networks. Network Management System (NMS) is in the form of a supermicro 183 series server device, for monitoring GSM backup networks that exist on lastmile routers. In order for the GSM backup network to be monitored, Zabbix monitoring software is used by accessing the internet using an intermediate Mikrotik 951 router series. The Microtik router serves as a liaison between the Network Management System (NMS) and the internet so that the GSM backup network can be monitored by Zabbix.

\section{B. Monitoring Results}

The protocol used in monitoring Zabbix is the Internet Control Message Protocol (ICMP), which continuously pings the M2M SIM card IP address every 2 seconds. The M2M SIM card or host is said to have a fault so it will appear on Zabbix when it doesn't get a reply and requests time out as much as 7 times. However, the interference can be completed by itself in approximately 15 minutes because the cause of the interference is due to the signal obtained from the antenna is not good. Although the GSM network is only a backup but there is still traffic, so when the main network is interrupted, the backup network can be used immediately. Monitoring is done on Recent problems pages to see in real time the latest disturbances that are happening and that have been completed. The analysis is carried out on the host that is experiencing interference by ensuring that the host is indeed unable to reply to the ICMP ping packet that was performed. Before analyzing the results of monitoring, first know how to read the results of monitoring that are displayed on Zabbix. The following is the display of monitoring results.

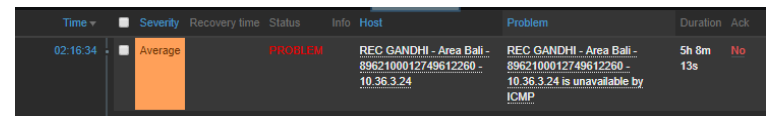

Fig. 2. Monitoring Result

The following is an explanation of the monitoring results above. 
Table 2.

explanation of the monitoring results

\begin{tabular}{|c|c|c|}
\hline column & Isi & Keterangan \\
\hline Time & $\begin{array}{l}\text { The time when } \\
\text { the host starts } \\
\text { to experience } \\
\text { interference }\end{array}$ & \\
\hline Severity & $\begin{array}{l}\text { Levels of } \\
\text { interference }\end{array}$ & $\begin{array}{l}\text { The level when } \\
\text { experiencing } \\
\text { interference or not } \\
\text { the same is } \\
\text { "average", } \\
\text { however, different } \\
\text { in color, when } \\
\text { experiencing an } \\
\text { orange disorder } \\
\text { and when there is } \\
\text { no interference } \\
\text { green. }\end{array}$ \\
\hline $\begin{array}{c}\text { Recovery } \\
\text { time }\end{array}$ & $\begin{array}{l}\text { The time when } \\
\text { the host is } \\
\text { finished } \\
\text { experiencing } \\
\text { interference }\end{array}$ & \\
\hline Status & $\begin{array}{l}\text { Status } \\
\text { regarding } \\
\text { interference }\end{array}$ & $\begin{array}{l}\text { When } \\
\text { experiencing an } \\
\text { eating disorder the } \\
\text { status is a } \\
\text { "problem", while } \\
\text { when you have a } \\
\text { disorder the status } \\
\text { is "resolved". }\end{array}$ \\
\hline Host & $\begin{array}{l}\text { Information } \\
\text { about } \\
\text { substation } \\
\text { codes - } \\
\text { substation area } \\
\text { - ICCID SIM } \\
\text { card number - } \\
\text { SIM card IP } \\
\text { address }\end{array}$ & \\
\hline
\end{tabular}

\begin{tabular}{|c|c|c|}
\hline Problem & $\begin{array}{l}\text { Information } \\
\text { about problems } \\
\text { that cause } \\
\text { interference }\end{array}$ & $\begin{array}{l}\text { 10.36.x.x is } \\
\text { unavailable by } \\
\text { ICMP which } \\
\text { means that it } \\
\text { cannot be pinged } \\
\text { using the ICMP } \\
\text { package. }\end{array}$ \\
\hline Duration & $\begin{array}{l}\text { The duration } \\
\text { when the host } \\
\text { is experiencing } \\
\text { interference }\end{array}$ & \\
\hline Ack & $\begin{array}{l}\text { Additional } \\
\text { information } \\
\text { from super } \\
\text { admin }\end{array}$ & $\begin{array}{l}\text { When there is no } \\
\text { additional } \\
\text { information, the } \\
\text { status is "no", } \\
\text { while when there } \\
\text { is additional } \\
\text { information, the } \\
\text { status is "yes" and } \\
\text { is green. }\end{array}$ \\
\hline
\end{tabular}

After knowing how to read the results of monitoring, the next step is to analyze the results of the monitoring carried out by clicking on the host name that has been disturbed in the Host column. There are several tools that can be used in analyzing monitoring results, namely Ping, Traceroute, Host inventory, Latest data, and Triggers. However, to analyze the results of monitoring, only use two tools, namely, Ping and Traceroute. The following are the test results using ping and traceroute on the repaired substation.

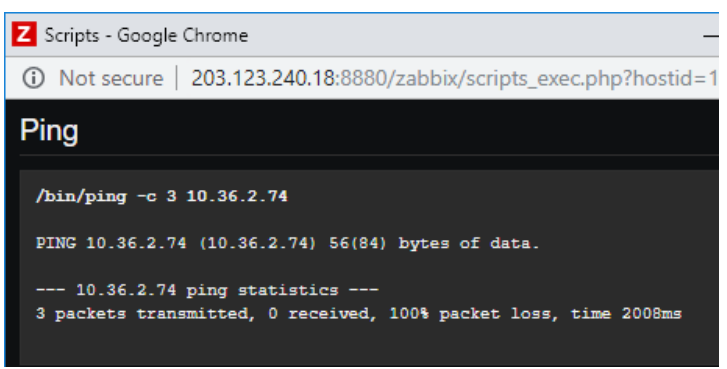

Fig. 3. Ping Result

After the ping test is done, the results obtained are, the host who experiences the interference does not get a reply or reply at all. In the picture above there is a description of "3 transmitted packets, 0 received, $100 \%$ packet loss, time $2008 \mathrm{~ms}$ " which means that 3 
packets sent were not received and the $100 \%$ packet was lost.

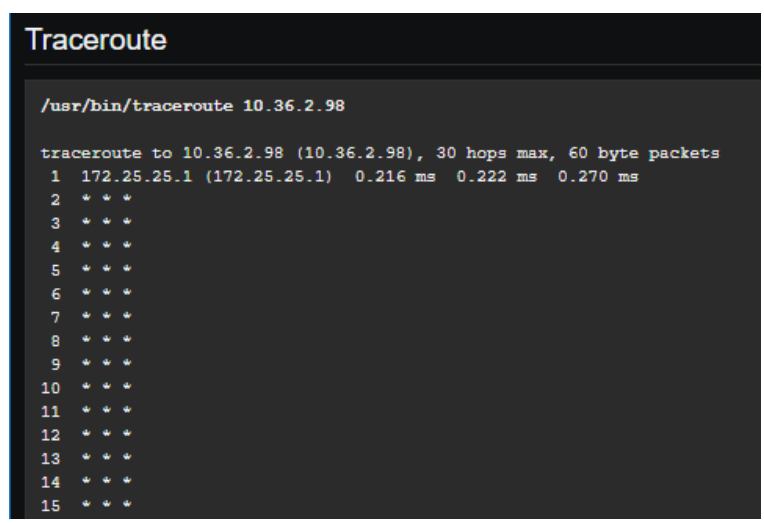

Fig. 4. Traceroute Result

traceroute is used to display the route used when doing a ping test. When the host is interrupted, when selecting traceroute no route is displayed. Even to the maximum hop or jump limit (30 hops) there is also no route displayed.

\section{RESULT}

\section{A. Handling Disorders Using SecureCRT)}

Interference with the M2M SIM card can be completed automatically in approximately 15 minutes because the cause of the interference is due to the signal obtained from the antenna is not good. If the disturbance does not end in more than 3 hours, the problem must be addressed immediately. SecureCRT is a terminal emulation software. SecureCRT is used to telnet against lastmile routers that have interference with M2M SIM cards. In using SecureCRT software, companies must register an admin to access the GSM backup network through SecureCRT software.

Handling is done by telneting to the lastmile router located on the substation that has a faulty M2M SIM card. Before you can telnet to a lastmile router, you must telnet to the router at the substation. If you successfully telnet to the router at the substation, what you have to do is look at the interface vlan to get the IP address. The IP address that is obtained will be used to telnet to the lastmile router. After that, looking at the IP interface brief to see if cellular0 has its IP address, if it is interrupted then the cellular0 IP address is likely to be missing or unassigned. The last step is to reset the router. However, if the interference is not resolved or completed too, it must be checked directly into the substation and report to the Icon Plus.
Table 3.

Steps in Dealing with Disorders

\begin{tabular}{|c|c|c|}
\hline No & Action & Function \\
\hline 1 & $\begin{array}{l}\text { Type command } \\
>>\text { fs (substation code) }\end{array}$ & $\begin{array}{l}\text { This command } \\
\text { displays the } \\
\text { filesystem at the } \\
\text { substation. On the } \\
\text { filesystem there is } \\
\text { the name of the } \\
\text { substation router } \\
\text { and the VLAN used }\end{array}$ \\
\hline 2 & $\begin{array}{l}\text { Typecommand } \\
\text { >>telnet (the name of } \\
\text { the substation router) }\end{array}$ & $\begin{array}{l}\text { This command is for } \\
\text { telnet or remote to } \\
\text { the router at the } \\
\text { substation using the } \\
\text { router name } \\
\text { obtained from the } \\
\text { filesystem. }\end{array}$ \\
\hline 3 & $\begin{array}{l}\text { Type command } \\
\text { >>sh int (VLAN) }\end{array}$ & $\begin{array}{l}\text { This command is to } \\
\text { see the interface or } \\
\text { description of the } \\
\text { VLAN used, } \\
\text { wherein there is an } \\
\text { IP address to telnet } \\
\text { to the lastmile } \\
\text { router. }\end{array}$ \\
\hline 4 & $\begin{array}{l}\text { Type command } \\
\text { >>telnet(IPaddress+1) } \\
\text { /vrf WAN-SCADA- } \\
\text { RTU-Dxxxx }\end{array}$ & $\begin{array}{l}\text { This command is for } \\
\text { telnet or remote to } \\
\text { lastmile router. }\end{array}$ \\
\hline 5 & $\begin{array}{l}\text { Type command } \\
\text { > sh ip int br }\end{array}$ & $\begin{array}{l}\text { This command } \\
\text { displays the } \\
\text { interface brief of the } \\
\text { lastmile router. } \\
\text { Then check whether } \\
\text { cellular0 gets an IP } \\
\text { address, because if } \\
\text { you experience } \\
\text { interference, you } \\
\text { will not get an IP } \\
\text { address. Can be seen } \\
\text { underlined. }\end{array}$ \\
\hline 6 & $\begin{array}{l}\text { Type command } \\
\text { >>conf } \mathrm{t} \\
\text { >>service internal } \\
\text { >> exit } \\
\text { >>test cellular } \quad 0 \\
\text { modem reset }\end{array}$ & $\begin{array}{l}\text { This command is to } \\
\text { reset a modem or } \\
\text { lastmile router that } \\
\text { was previously } \\
\text { performed by an } \\
\text { internal service to } \\
\text { optimize the results } \\
\text { when resetting. }\end{array}$ \\
\hline 7 & $\begin{array}{l}\text { Do steps } 2 \text { to } 7 \text { again, } \\
\text { then type the } \\
\text { command } \\
\text { > sh ip int br }\end{array}$ & $\begin{array}{l}\text { This command is to } \\
\text { check again whether } \\
\text { Cellular0 has } \\
\text { received the IP } \\
\text { address or not. After }\end{array}$ \\
\hline
\end{tabular}




\begin{tabular}{|l|l|}
\hline & $\begin{array}{l}\text { a modem is reset, } \\
\text { the IP address of } \\
\text { cellular0 already } \\
\text { exists, and the } \\
\text { interference has } \\
\text { been completed. }\end{array}$ \\
\hline
\end{tabular}

\section{V.CONCLUSION}

Almost all activities carried out now require electricity, both activities at home, in the office or in public places. monitoring the status of the distribution substation can provide many benefits for the entire community and make it easier for officers to handle the electricity supply so that the electricity supply can be fulfilled. By using Zabbix software, it can facilitate the NOC team to monitor GSM backup networks at PT $\mathrm{XYZ}$. The interference notification that is displayed on Zabbix runs well, so that if an interruption occurs it can be handled immediately. Handlers using SecureCRT software are less helpful in handling the disruption of M2M SIM cards, because not all interference can be handled using SecureCRT.

\section{REFERENCES}

[1] Prayudha, R. B., Murtty, M. A., \& Pangaribuan, P. (2015). Desain dan Implementasi Scada (Supervisory Control And Data Acquisition) pada Sistem Boiler Drum Menggunakan PLC Omron. eProceeding of Engineering, 1989-1994.

[2] Suzuki, K., \& Azuma, T. (2014). Standardization of Embedded UICC Remote Provisioning. NTT DOCOMO Technical Journal, 36-41.

[3] Yonida, R. E. (den 27 Juni 2014). Telkomsel Hadirkan Layanan M2M untuk Bisnis di Indonesia. Jakarta, DKI Jakarta, Indonesia.

[4] Pratama, M. R., Munadi, R., \& Hafidudin, H. (2017). Implementasi dan Analisis Sistem Monitoring Menggunakan Simple Network Management Protocol (SNMP) pada Gedung A,N,O di Jaringan Telkom University . eProceeding of Engineering, 2092-2099.

[5] Cisco. (den 20 Desember 2018). Network to Network Interface Configuration. Hämtat från Cisco: www.cisco.com

[6] Aziz, F. I., Adhi P., B., \& Ritzkal. (2017). Sistem Monitoring Jaringan dan Optimalisasi Manajemen Bandwidth dengan Algoritma HTB (Hierarchical Token Bucket) pada Zabbix dengan Notifikasi SMS Gateway Dan Email (Studi Kasus Dinas Komunikasi Dan Informatika Kab. Bogor).
PROSIDING SEMINAR NASIONAL ENERGI \& TEKNOLOGI (SINERGI) 2017, 231-245.

[7] SecureCRT. (den 20 December 2018). SecureCRT. Hämtat från VANDYKE Software: https://www.vandyke.com 